\title{
Disentangling grazing and light controls on algal communities in grassland and afforested streams
}

\author{
Luciana Cibils-Martina $^{1,2}$ | Javier A. Márquez ${ }^{1,2} \mid$ Elena Noemí Gari ${ }^{1}$ | Ricardo J. Albariño ${ }^{2,3}$ | \\ Romina E. Principe ${ }^{1,2}$
}

${ }^{1}$ Departamento de Ciencias Naturales, Universidad Nacional de Río Cuarto (UNRC), Córdoba,

Argentina

${ }^{2}$ CONICET, Buenos Aires, Argentina

${ }^{3}$ Laboratorio de Fotobiología, INIBIOMA, Universidad Nacional del Comahue CONICET, Bariloche, Argentina

Correspondence

Luciana Cibils-Martina, Departamento de Ciencias Naturales, Universidad Nacional de Río Cuarto (UNRC), Córdoba, Argentina.

Email: lcibils@gmail.com

\begin{abstract}
Our aim was to analyze the combined effect of grazing and light on composition, structure, functional diversity (FD) and succession of algal communities in two headwater streams (grassland and pine afforested). We hypothesized that algal communities in the grassland stream are top-down controlled, as a result of higher grazing; meanwhile, in the afforested stream, algal communities are bottom-up shaped, mainly due to sunlight reduction. In in situ experiments, we used platforms to avoid grazing in both streams, and the substrates were extracted at 23, 45 and 73 days. Algal community composition was different between stream types. Seventy percent of structural and biomass variables responded to grazing. In the grassland stream, grazing reduced richness and ash-free dry mass (AFDM), especially after 45 days, while in the afforested stream, at the same time, grazed substrates showed higher richness and AFDM than ungrazed substrates. Net grazing effect was higher on algal biomass of grassland streams. Then, $30 \%$ of functional traits showed grazing effect. High profile algae predominated in the grassland stream, where ungrazed substrates showed higher proportions of species with pad mucilage and colonial life form. Algal communities in the afforested stream remained at an early stage of succession, with a predominance of small and low profile algae in both substrates, and FD and evenness indices were lower. Our results indicate that the relative strength of top-down versus bottom-up control is different among stream types and the primary regulatory factor of freshwater communities can be modified according to such forestry practice.
\end{abstract}

\section{KEYWORDS}

bottom-up, exotic pines, grassland, periphyton, top-down

\section{1 | INTRODUCTION}

The conversion of grasslands into forests for timber production has become a common phenomenon in the southern hemisphere over the past 50-70 years (Jobbágy et al., 2006; Raffaele, Núñez, \& Relva, 2015; Simberloff et al., 2010). To maximize timber yields, grassland catchments are often planted with trees up to the stream margins. Grassland afforestation of stream margins has drastic consequences to stream ecosystems as they modify the sunlight input to fluvial systems, especially when tree species are evergreen (Thompson \& Townsend, 2005). A small, open-canopy stream with high levels of benthic algal production is likely to change if shaded. Algal growth and standing stock will be reduced and food webs may turn "brown" if allochthonous detritus becomes the primary energy source (Dodds, Gido, Whiles, Fritz, \& Matthews, 2004; Thompson \& Townsend, 2005; Whiting, Whiles, \& Stone, 2011). In Argentina, semiarid lands were afforested in the late 1970s as a result of a tax deferral plan implemented by the government. 
Approximately 36,000 ha of the Comechingones mountains in Córdoba were afforested with exotic pines between 900 and 1,600 m above sea level (a.s.l., Plevich, Nuñez, Cantero, Demaestri, \& Viale, 2002), which corresponds to $15 \%$ of upland grasslands. Farley, Piñeiro, Palmer, Jobbágy, and Jackson (2008) showed that pine afforestation in this area did not alter stream water acidity, although a $50 \%$ reduction in annual water yield was reported in afforested streams (Jobbágy, Acosta, \& Nosetto, 2013). Previous studies in the area, comparing three afforested and three grassland streams, found that algal abundance, richness and indicator taxa were reduced in afforested streams compared to grassland ones (Cibils-Martina, Márquez, Principe, Gari, \& Albariño, 2017). Furthermore, benthic invertebrates were heavily reduced under afforestation (mean density grassland streams: $23,180 \mathrm{ind} / \mathrm{m}^{2}$, mean density afforested streams: 6,880 ind $/ \mathrm{m}^{2}$, Márquez, Cibils, Principe, \& Albariño, 2015).

Under this new scenario following stream afforestation, algal-grazer interactions may be modified. Herbivory may have different, predictable effects on succession rates depending upon the growth forms available in the local species pool, and whether the more susceptible forms are early or late successional species (Díaz Villanueva \& Modenutti, 2004; Tuchman \& Stevenson, 1991). Hillebrand (2005) stated that grazer effects become stronger at high light supply, which indicated that high light favours algal growth types that are easily ingested and a community dominated by photosynthetic organisms. However, filamentous forms and high proportions of mucilage, which may be abundant in high light conditions, are difficult to graze (Wellnitz \& Ward, 1998). Cibils-Martina, Principe, Márquez, Gari, and Albariño (2017) found that in an afforested stream, succession proceeded toward the dominance of prostrate, lowprofile species, tolerant of low-light conditions. However, in grassland streams with higher sunlight availability, highprofile algae prevailed. Thus, algal community architecture can be different according to environmental conditions, with consequences through the food web. Stalked or high profile growth forms could outcompete other growth forms for light due to the erect structure, but in the presence of grazers, these same taxa may be disadvantaged due to higher consumption rates (Holomuzki, Feminella, \& Power, 2010; Steinman, 1996).

The relative importance of top-down control by herbivores and bottom-up control by environmental conditions on primary production within ecosystems has been the subject of a long-standing debate in ecology (Elschot et al., 2017; Gruner et al., 2008; Hunter \& Price, 1992). Environmental conditions may determine the direction and magnitude of top-down and bottom-up forces that control freshwater communities and influence species diversity (Thompson \& Townsend, 2005; Werner \& Matthiessen, 2013). In open mountain streams, benthic algae represent the primary production supporting food webs (Roberts, Sabater, \& Beardall, 2004), and their development is shaped by abiotic factors, such as resources (light, nutrients) and stressors (current shear stress, $\mathrm{pH}$, salt, heavy metals), but also biotic factors, as positive (commensalism, mutualism) or negative (competition, grazing) interactions (Stevenson, 2010). Therefore, there are bottom-up and top-down forces that regulate the taxonomic and functional structure of algal communities, the rate and direction of succession (Larson \& Passy, 2012) and their biomass (Hillebrand, 2002). The importance of species interactions in structuring ecological communities or regulating community processes within and among ecosystems has long been subject of interest to ecologists (Power et al., 1996). Many studies have shown the effect of grazers on algal biomass (Feminella \& Hawkins, 1995; Lamberti, Ashkenas, Gregory, \& Steinman, 1987; McNeely, Finlay, \& Power, 2007; Rober, Stevenson, \& Wyatt, 2015; Steinman, 1996; Taylor, McIntosh, \& Peckarsky, 2002), composition (Abe, Uchida, Nagumo, \& Tanaka, 2007; Díaz Villanueva \& Modenutti, 2004), architecture (Wellnitz \& Ward, 2000) and spatial heterogeneity (Álvarez \& Peckarsky, 2005; Flecker \& Taylor, 2004). Furthermore, there are studies of stream periphyton that emphasize the relationship between algal-grazer interactions and irradiance (Hill, Ryon, \& Schilling, 1995; Lange, Liess, Piggott, Townsend, \& Matthaei, 2011; Mallory \& Richardson, 2005; Rosemond, Mulholland, \& Brawley, 2000; Steinman, McIntire, Gregory, \& Lamberti, 1989; Wellnitz \& Rader, 2003; Wellnitz \& Ward, 1998, 2000; Winkelmann et al., 2014). However, to our knowledge, few studies have analyzed the effects of riparian vegetation changes on algal-grazer interactions and the effects of grazing on the succession of algal communities (Díaz Villanueva \& Modenutti, 2004; Tuchman \& Stevenson, 1991).

Cibils Martina, Márquez, Principe, Gari, and Albariño (2014) showed that larvae of the Trichoptera Helicopsyche, a common and abundant scraper, exerted greater control on algal communities developed in a grassland stream than when they were grown in an afforested one; they argued that stronger grazing was stimulated by higher periphyton quality (more autotrophic and with higher digestible organic matter) belonging to grassland streams. Principe, Márquez, Cibils Martina, Jobbágy, and Albariño (2015) which performed a 30-day field experiment in the same streams of this study with only grazing-exposed substrates, found that biofilm accrual (i.e., biomass per surface unit and time) was similar between three grassland and three afforested streams. Overall, those results suggest that opposing forces happening in grassland (high light levels plus strong grazing) and pine streams (low light and weak grazing) resulted in similar accrual rates. Long-term experiments, of more than 2 months of duration, provide a more realistic description of the herbivore role in streams, given that ungrazed treatments 
capture better the temporal variability that periphyton would exhibit in absence of grazers (Feminella \& Hawkins, 1995).

Our aim was to analyze the combined effect of grazing and light on composition, structure and succession of algal communities in two different headwater streams (grassland and afforested), with a long-term, field experiment. We manipulated grazing intensity by placing substrates on the bottom (ambient grazing) or elevated (reduced grazing) in grassland and afforested streams. We hypothesized that algal communities in the grassland stream are top-down controlled, by higher grazing; meanwhile, in the afforested stream, algal communities are bottom-up controlled, due to sunlight reduction (Figure 1). We expected that (a) greater sunlight exposure occurring in the grassland stream would favour the development of algal communities, especially grazing-vulnerable algal species. Therefore, the difference between grazed and ungrazed substrates would be higher than in the afforested stream. In this stream, (b) sunlight reduction would limit the development of algae in both substrates, so there would be no differences between treatments. In addition, we expected that (c) succession reaches an advanced senescent stage in ungrazed substrates in the grassland stream (i.e., higher proportion of high profile species) and that algal communities remain in an earlier stage of development, dominated by low profile species, on both substrates in the afforested stream.

\section{2 | MATERIALS AND METHODS}

\subsection{Study area}

The study was carried out in two streams of the Ctalamochita River upper basin, Córdoba, Argentina. This river is one of the main tributaries of the Carcarañá River and belongs to La Plata River basin. Headwaters of the Ctalamochita river are located in grasslands of the Comechingones mountains between 800 and 1,500 m a.s.l. The area of highland grassland and tabaquillo forests of the central Pampean Ranges of central Argentina have been classified as a biogeographic province belonging to the South American transition zone (Martínez, Arana, Oggero, \& Natale, 2016). The lithology is dominated by granitic rocks with localized patches of metamorphic rocks (gneiss, schist, migmatite). Annual precipitation in the region reaches $725 \mathrm{~mm}$, occurring mostly between spring and the end of summer
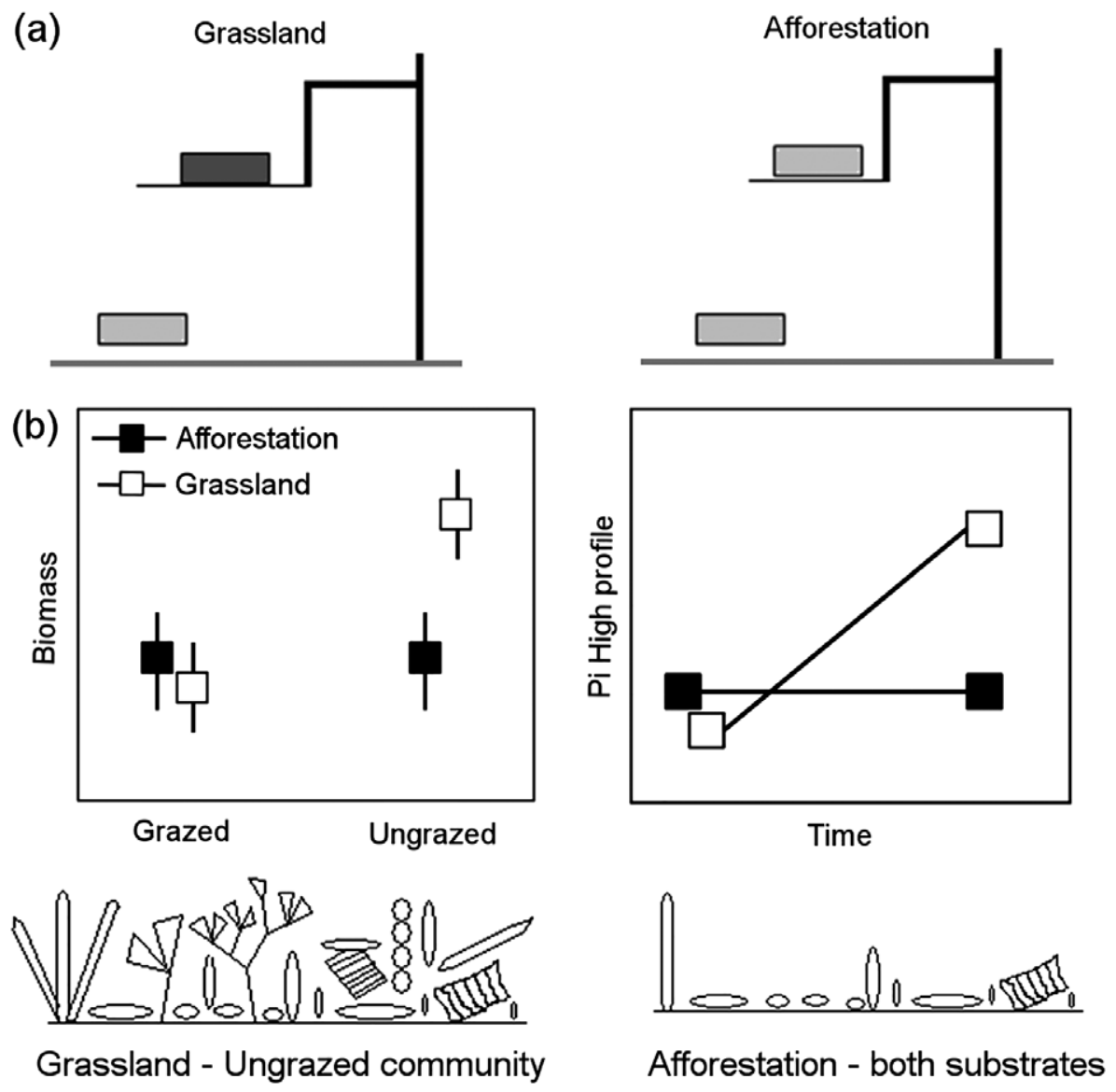

FIGURE 1 Conceptual graph of hypothesis and predictions: (a) algal communities in the grassland stream are top-down controlled, by higher grazing; meanwhile, in the afforested stream, algal communities are bottom-up controlled, due to sunlight reduction, so the difference in algal biomass between grazed (G) and ungrazed (UnG) substrates would be higher in the grassland stream than in the afforested stream, represented by different color of the substrates.

(b) Succession reaches an advanced stage in ungrazed substrates in the grassland stream (i.e., higher biomass and proportion of high profile species) and algal communities remain at an earlier stage of development on both substrates in the afforested stream 
(October-March) (Cabido et al., 2003). The maximum temperature reaches $34{ }^{\circ} \mathrm{C}$ in summer (December-March) and decreases to as low as $-5{ }^{\circ} \mathrm{C}$ in winter (June-September). Vegetation varies according to altitude, with native grassland developing between 1,000 and 1,500 m a.s.l. (mainly Festuca hieronymi Hack., Nasella spp., Schizachyrium condensatum [Kunth] Nees and Eragrostis airoides Nees; Cabido et al., 2003; Oggero \& Arana, 2012). The study area is affected by anthropogenic activities, mainly livestock and afforestation with exotic pines. Pinus elliottii Engelm. is the most abundant in the plantations.

\subsection{Experimental design and laboratory methods}

We selected two first-order streams which were $1 \mathrm{~km}$ apart with similar altitude, slope, and drainage area. One stream drains grasslands $\left(31^{\circ} 58^{\prime} 47^{\prime \prime} \mathrm{S}, 64^{\circ} 48^{\prime} 41^{\prime \prime} \mathrm{W}, 1175 \mathrm{~m}\right.$ a.s.l., drainage area $87 \mathrm{ha}$ ), and the neighbouring stream drains a plantation of $P$. elliottii $\left(31^{\circ} 59^{\prime} 22^{\prime \prime} \mathrm{S}, \quad 64^{\circ} 48^{\prime} 44^{\prime \prime} \mathrm{W}\right.$, $1144 \mathrm{~m}$ a.s.l., drainage area 89 ha fully covered by the plantation). We performed a field grazing experiment by placing artificial substrates on the bottom (grazed) or elevated in platforms (ungrazed) in the grassland and the afforested streams, and extracting substrates at three different dates. We placed four platforms at different riffles of each stream. We conducted the experiment during the low flow season (July-September 2012) in order to avoid flooding effects on communities and experimental devices. At the beginning of the experiment we registered water depth, current velocity, dominant substrate type and channel wet width in four riffles, each corresponding to the location of tiles in each stream. Depth, width and current velocity were measured with a digital water velocity meter (Global Flow probe FP101), while substrate type was visually assessed (Gordon, Mcmahon, \& Finlayson, 1994) and assigned to a category proposed by Thomson, Taylor, Fryirs, and Brierley (2001). Current velocity was measured for bottom and elevated substrates. Some physicochemical parameters were measured three times at each stream during the experiment, coinciding with the extractions of tiles for algal community analysis: photosynthetically active radiation (PAR) intensity, $\mathrm{pH}$, conductivity, temperature, total dissolved solids (TDS), carbonates, bicarbonates and nitrates. The PAR intensity was measured with a QSL-2100 Irradiance Sensor (Biospherical Instruments Inc., San Diego, CA) over the water surface midday along a $50 \mathrm{~m}$ reach in each stream. Water $\mathrm{pH}$, conductivity and temperature were recorded with portable sensors. TDS, carbonates, bicarbonates and nitrates were analyzed by the area of Hydrology, Department of Geology, National University of Río Cuarto, according to standard methods (American Public Health Association [APHA], 1998). Carbonates and bicarbonates were measured by potentiometric titration with a Thermo Orion-selective electrode, while nitrates were determined by potentiometry using an ion selective electrode (Orion Model 9307), a reference electrode and an Orion potentiometer 710 A. To calibrate the potentiometer, six benchmarks $(5,10,25,50,100$ and $300 \mathrm{mg} / \mathrm{L}^{1} \mathrm{NO}_{3}{ }^{-}$) were used. The detection limit for $\mathrm{NO}_{3}{ }^{-}$ was $0.2 \mathrm{mg}$ of $\mathrm{NO}_{3}{ }^{-} \mathrm{L}^{-1}$ and the analytical error of the measurements was $0.5 \%$.

We used 60 unglazed tiles of $7.5 \times 7.5 \mathrm{~cm}$ as artificial substrates. To avoid grazing, we elevated half substrates $8-15 \mathrm{~cm}$ from the bottom and $2-4 \mathrm{~cm}$ under the water surface using a platform design with $\mathbf{J}$ inverted metal bars (Lamberti, Feminella, \& Pringle, 2007). We placed the other half of the substrates in the bottom of each stream, exposed to grazers, next to $\mathbf{J}$ inverted metal bars (Figure 2). We placed metal bars in riffles of $1.4 \mathrm{~m}$ mean width, $10-60 \mathrm{~cm}$ from the nearest margin. This method excludes benthic grazers that do not swim or that exhibit low drift rates, but allows swimming or drifting nontarget species (e.g., mayflies, chironomids) to reach the platforms; thus, elevated tiles were controlled every 7-10 days, removing and collecting macroinvertebrates (Lamberti et al., 2007). Density of benthic invertebrates registered previously in grassland and afforested streams were 23,180 and 6,880 ind $/ \mathrm{m}^{2}$ (Márquez et al., 2015). We extracted five tiles from each grazing treatment for each stream at 23, 45 and 73 days of exposure. At

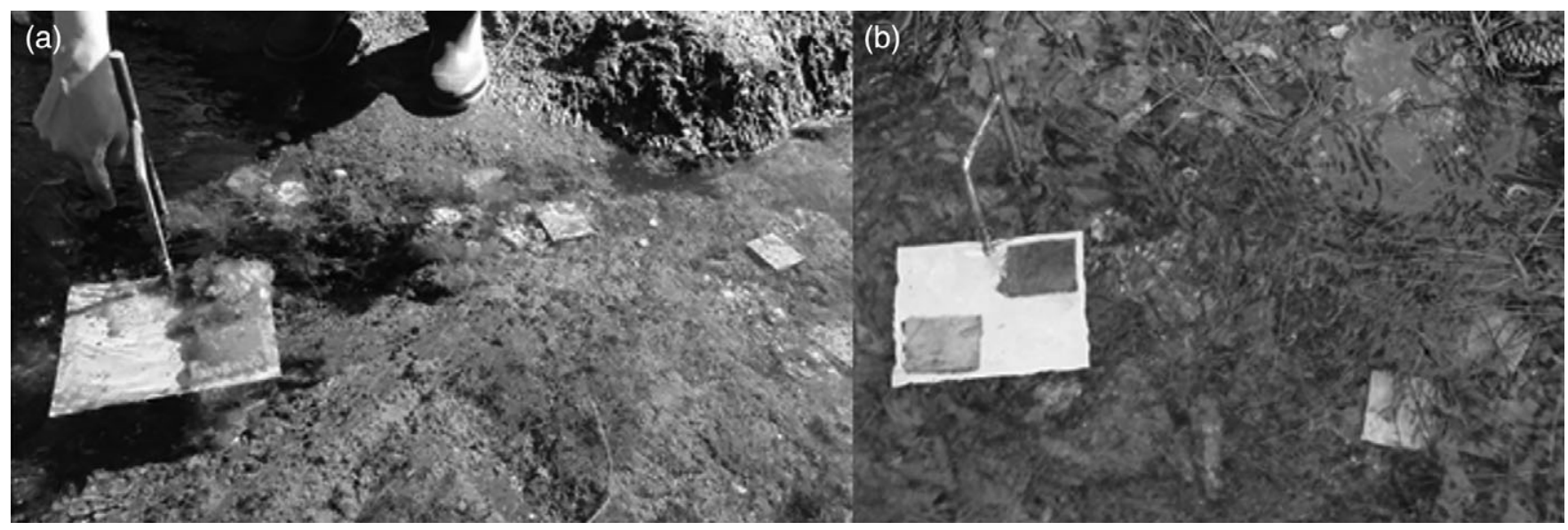

FIGURE 2 Grazed and ungrazed substrates at 54 days in the (a) grassland and (b) afforested streams 
each extraction date, we took tiles to the laboratory in individual plastic containers refrigerated and in darkness. We scrubbed off algae from the upper surface of the substrates with a stiff nylon brush, after which, they were rinsed with clean tape water and all the dislodged material was collected. We homogenized and fractionated the periphyton suspension in three subsamples. We filtered one fraction through a preincinerated and preweighed glass-fibre filter MF/C $(1.2 \mu \mathrm{m}$ pore size, Munktell, Sweden), we dried it for $48 \mathrm{hr}$ at $60^{\circ} \mathrm{C}$, weighed it (to the nearest $0.01 \mathrm{mg}$ ), combusted at $500^{\circ} \mathrm{C}$ for $1 \mathrm{hr}$, and reweighed it, to determine ash-free dry mass (AFDM). We used another fraction to extract and quantify chlorophyll a ( $\mathrm{Chl} a$ ) concentration by $90 \%$ ethanol extraction in a hot bath and spectrophotometry (Nusch, 1980). We then calculated the autotrophic index from the Chl $a$ and AFDM values (AI = AFDM in $\mathrm{mg} / \mathrm{m}^{2}: \mathrm{Chl} a$ in $\mathrm{mg} / \mathrm{m}^{2}$ ) for each substrate replicate (Weber, 1973); biofilm is considered to be more heterotrophic with higher values (Biggs \& Kilroy, 2000). We fixed the third fraction with $4 \%$ formalin and used it for algal identification and density calculations. We analyzed algal communities quantitatively at $\times 400$ magnification with organisms grouped taxonomically by genus. For each sample, we counted three subsamples following transects along the coverslip to determine cell densities (cells $/ \mathrm{cm}^{2}$, based on Villafañe \& Reid, 1995). The counting unit was an individual cell for unicellular and coenobial organisms, a $10 \mu \mathrm{m}$ length for filaments and a $10 \times 10 \mu \mathrm{m}$ area for colonies.

\section{3 | Data analysis}

We compared environmental variables between the grassland and the afforested stream using one-way ANOVA for those registered at the beginning of the experiment in four riffles at each stream, and repeated measures ANOVA for those measured three times at each stream.

We evaluated differences in benthic algal communities between riparian vegetation types, grazing treatments and time using nonmetric multidimensional scaling (NMDS) based on the Bray-Curtis dissimilarity matrix, and analysis of similarities (ANOSIM) to statistically test differences between groups. For these analyses, we used square root transformed abundance to decrease the influence of abundant species. Additionally, we performed similarity percentages (SIMPER) analysis to determine which species contributed most to the dissimilarity between sampling units (Clarke \& Warwick, 2001; Quinn \& Keough, 2002). We constructed rank-abundance curves with selected species (relative abundance $>1 \%$ ) of grazed and ungrazed substrates of the grassland and the afforested streams. We calculated relative abundance ( $\mathrm{Pi}$ ) and ordered species from the commonest to the less abundant in each stream and substrate type. Thus, these curves visually represent the changes in dominant species between streams.
We calculated structural attributes of algal communities: density, richness and Shannon diversity $\left(\mathrm{H}^{\prime}\right)$ and evenness $\left(\mathrm{J}^{\prime}\right)$ indices (calculated from algal densities and using $\log _{10}$ in the formula). In addition, we assigned the genera to categories of some functional traits according to Cibils, Principe, Márquez, Gari, and Albariño (2015): size, morphological guild, attachment mechanism and life form (Table S1, Supporting Information). With these traits, we calculated two measures of functional diversity (FD) (Heino, 2005): FD, that is, Shannon-Wiener diversity index, describing both the number of functional groups and the division of individuals among the functional groups, and functional evenness (FE), based on Shannon-Wiener index and describing the division of individuals among the functional groups. We compared structural variables, $\mathrm{Chl} a$, AFDM, AI, the proportion of algae corresponding to different categories of functional traits, FD and FE using repeated measures ANOVA, with three fixed factors: riparian vegetation (grassland-afforestation), grazing (grazed-ungrazed) and extraction time (23-45-73 days), and $\mathrm{J}$ inverted bars as a random factor. We calculated the NGE (modified from Buria, Albariño, Díaz Villanueva, Modenutti, \& Balseiro, 2010) considering removal by feeding and movement activities as:

$$
\mathrm{NGE}=\mathrm{UnG}-\mathrm{G}
$$

where UnG is the Chl $a$ or AFDM in ungrazed substrates, G is the Chl $a$ or AFDM in grazed substrates, showing the net biomass removed by the grazer. We compared NGE on the grassland and the afforested communities for each extraction time with two-way ANOVA.

We performed multivariate analyses (NMDS, ANOSIM and SIMPER) in $\mathrm{R}$ version 3.3.2, using vegan library (Oksanen et al., 2013; R Core Team, 2013). We performed ANOVA using InfoStat, which implements an interface of platform $\mathrm{R}$ to estimate general and mixed linear models (Di Rienzo et al., 2012; Di Rienzo, Macchiavelli, \& Casanoves, 2011). We performed validations of assumptions of the models reviewing standardized residuals versus predicted, the normal Q-Q plot of standardized residuals and the Shapiro-Wilks test. Variables that did not meet ANOVA assumptions were natural logarithm transformed. The $\mathrm{Di}$ Rienzo-Guzman-Casanoves test, which is a hierarchical method that controls type I errors while maintaining acceptable power, was used for multiple comparisons.

\section{3 | RESULTS}

Environmental parameters were similar between grassland and afforested streams (Table 1). Predominant substrates in the afforested stream were boulders and cobbles, and in the grassland stream, bedrock was dominant. Current velocities were similar between streams and were not affected by the elevation of substrates. The PAR intensity was $70 \%$ lower in the afforested stream, and given the transparency of water 
TABLE 1 Environmental variables measured to characterize grassland and afforested streams

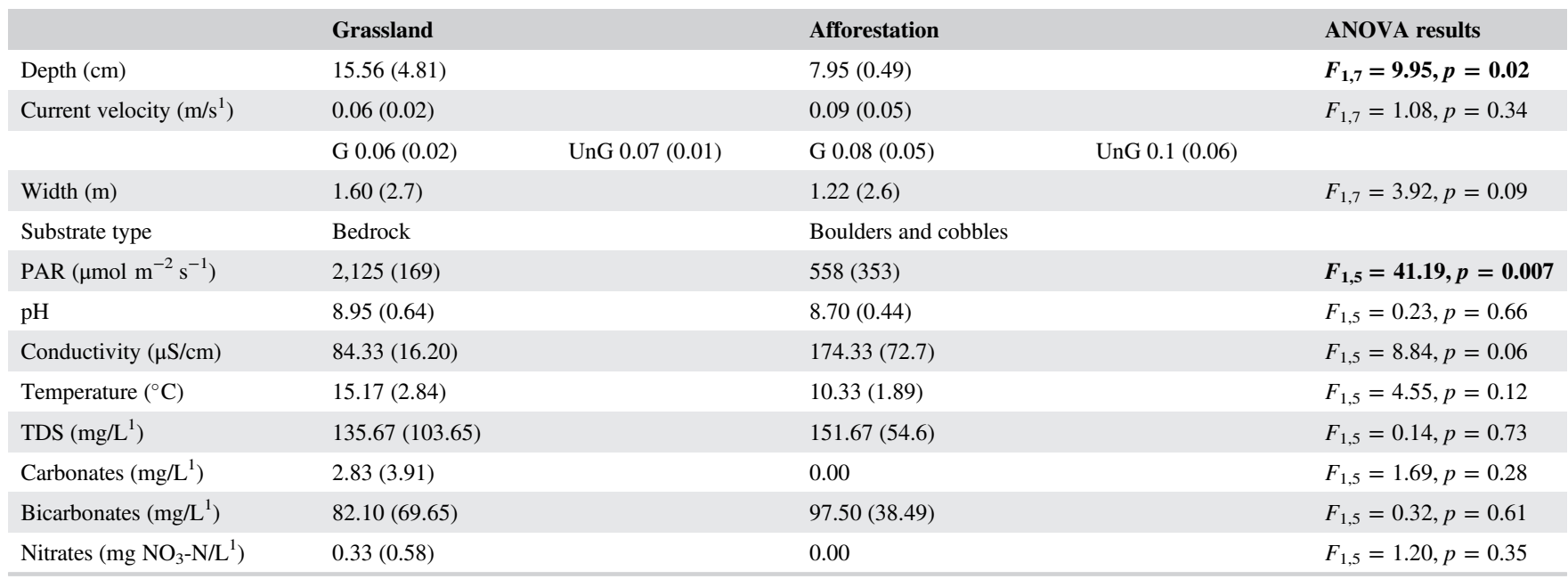

Notes. Mean values, $S D$ and results of ANOVAs ( $F, d f$ and $p$ values) are shown. Significant differences between grassland and afforested streams are in bold $(p<0.05)$. One-way ANOVAs were performed for depth, current velocity, width and repeated measures ANOVAs were performed for PAR, $\mathrm{pH}$, conductivity, temperature, TDS, carbonate, bicarbonate and nitrate. PAR $=$ photosynthetically active radiation; TDS $=$ total dissolved solids. $\mathrm{G}=$ grazed, UnG $=$ ungrazed substrates. $N=8$ for depth, current velocity and width, and $n=6$ for PAR intensity, $\mathrm{pH}$, conductivity, temperature, TDS, carbonates, bicarbonates and nitrates.

there were no differences between substrates. In addition, the afforested stream showed higher conductivity than grassland streams, although ANOVA was marginally significant (Table 1).

Metal bars effectively prevented grazer access and feeding, even when we found and removed occasional invertebrates in weekly inspections of ungrazed substrates (mean value along the experiment: one individual/substrate/stream). Densities in elevated substrates were $49 \mathrm{ind} / \mathrm{m}^{2}$ in the grassland stream and $167 \mathrm{ind} / \mathrm{m}^{2}$ in the afforested one, representing more than $90 \%$ of reduction in both cases. In substrates of the afforested stream, we found and collected mainly simuliids and chironomids, while ephemeropterans were present in ungrazed substrates in the grassland stream. Each week we photographed substrates, and gradually larger differences between grazed and ungrazed substrates in the grassland stream were apparent, compared to the afforested stream (Figure 2a,b). In grazed substrates of the grassland stream, Helicopsyche larvae were common.

Furthermore, in the grassland stream, there was a large growth of the algae Tetraspora lubrica (Roth) C. Agardh (Figure 2a) covering ungrazed substrates completely, mainly at 23 days. After 38 days of experiment, we observed a high volume of mucilage in substrates of the grassland stream, but they were absent 10 days before the final substrate removal. Biomass measured as $\mathrm{Chl} a$ increased with time, mainly in the grassland stream where it reached higher values in grazed substrates (Table 2, Figure 3a). AFDM also showed an increase with time, more evident in the grassland stream, where higher values occurred in ungrazed substrates contrasting with $\mathrm{Chl} a$. Autotrophic index depended on the interaction of the three factors, with higher values (mean value 1,400 ) in grazed tiles from the grassland stream in the second extraction date, and the lower values (mean value

TABLE 2 Repeated measures ANOVAs results for biomass and structural variables of algal communities developed in afforested (Af) and grassland (Gs) streams (factor vegetation), in grazed (G) and ungrazed substrates (UnG) (factor grazing), extracted at three dates (factor time, 1, 2 and 3)

\begin{tabular}{|c|c|c|c|c|c|}
\hline Variable & Factor & $d f$ & $\boldsymbol{F}$ & $p$ & A posteriori \\
\hline \multirow[t]{2}{*}{ Ln Chl $a$} & Veg $\times$ time & 2 & 5.69 & 0.006 & Af $1=$ Gs $1<$ Af $3=$ Gs $2=$ Af $2<$ Gs 3 \\
\hline & Veg $\times$ grazing & 1 & 6.22 & 0.02 & AfUnG $<$ GsG $=$ AfG $=$ GsUnG \\
\hline \multirow[t]{2}{*}{ AFDM } & Grazing $\times$ time & 2 & 4.49 & 0.02 & $\mathrm{UnG} 1=\mathrm{G} 1=\mathrm{G} 3<\mathrm{UnG} 2=\mathrm{UnG} 3=\mathrm{G} 2$ \\
\hline & Veg $\times$ grazing & 1 & 9.71 & 0.003 & AfUnG $<$ AfG $=$ GsG $<$ GsUnG \\
\hline Ln AI & Veg $\times$ grazing $\times$ time & 2 & 3.78 & 0.03 & $\begin{array}{l}\text { GsG3 < AfUnG2 = AfG2 = AfG3 = AfG1 = GsUnG2 = AfUnG1 } \\
\quad=\text { AfUnG3 = GsUnG3 = GsUnG1 = GsG1 < GsG2 }\end{array}$ \\
\hline \multirow[t]{2}{*}{ Ln density } & Veg $\times$ grazing & 1 & 4.75 & 0.04 & AfUnG $<$ AfG $=$ GsG $=$ GsUnG \\
\hline & Time & 2 & 18.21 & $<0.001$ & $1<2=3$ \\
\hline \multirow[t]{2}{*}{ Richness } & Veg $\times$ grazing & 1 & 7.87 & 0.02 & AfUnG $<$ AfG $=$ GsG $<$ GsUnG \\
\hline & Time & 2 & 11.18 & 0.002 & $1<2=3$ \\
\hline Diversity & Veg $\times$ time & 2 & 6.93 & 0.003 & Af $3=$ Af $2<$ Gs $1=$ Af $1=$ Gs $2=$ Gs 3 \\
\hline Evenness & Veg $\times$ time & 2 & 6.91 & 0.003 & Af $3=$ Af $2<$ Gs $1=$ Gs $2=$ Gs $3=$ Af 1 \\
\hline
\end{tabular}

Note. For each variable, factors that showed a significant effect are shown, with $F$ value, degrees of freedom, $p$ value and a posteriori results. 


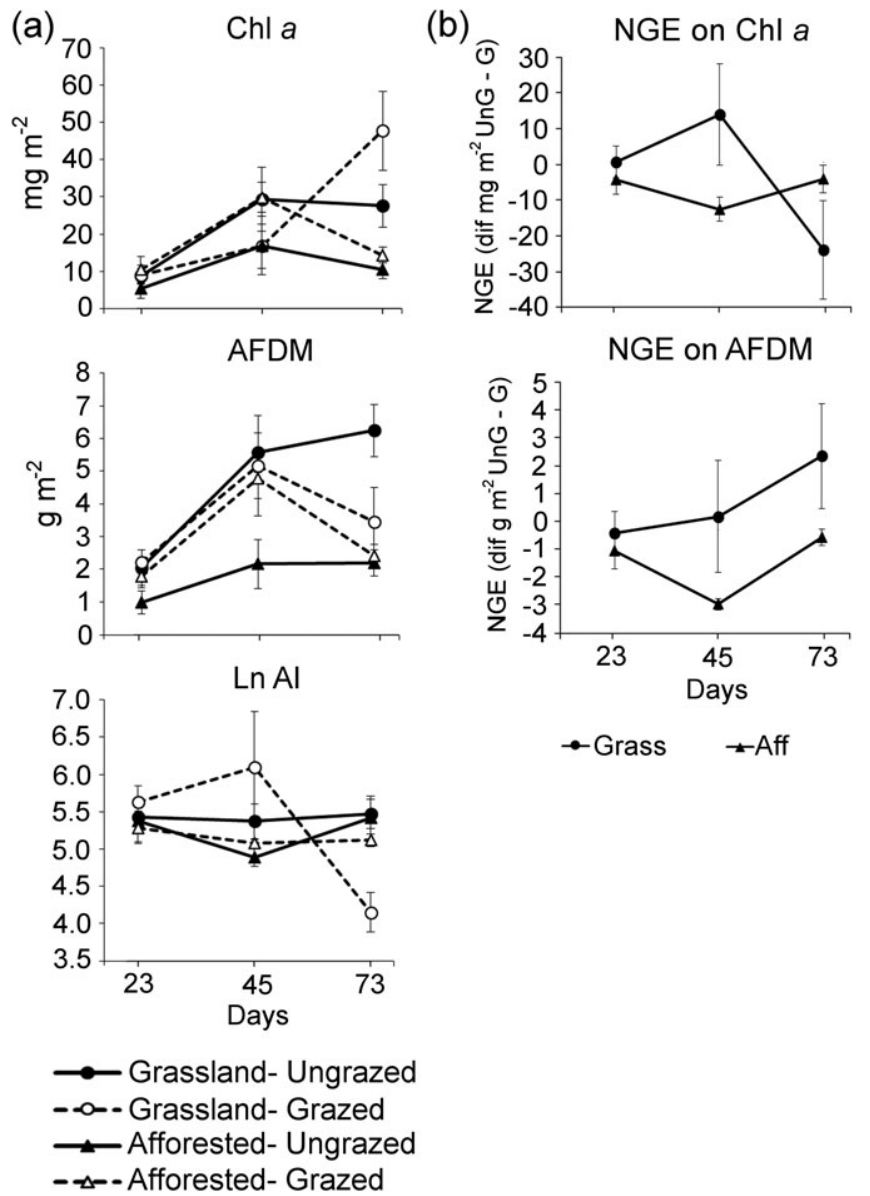

FIGURE 3 (a) Biomass variables of algal communities developed in the afforested and the grassland streams, in grazed and ungrazed substrates, extracted at 23, 45 and 73 days. (b) Net grazing effect (NGE) on Chl $a$ and on AFDM registered in the afforested and the grassland streams at 23, 45 and 73 days. For each variable, mean values and $S D$ are shown
70) in the same substrates but at 73 days. Respecting NGE, many negative values were obtained (Figure $3 b$ ). NGE on Chl $a$ showed differences between vegetation types but depending on extraction time $\left(F_{2,26}=4.74, p=0.02\right)$. At 23 days, there were no differences between the grassland and the afforested stream. At 45 days, NGE was higher in the grassland stream but at 73 days grazing effect was reduced. In the afforested stream, NGE was around zero. NGE on AFDM was higher in the grassland stream $\left(F_{1,26}=6.7, p=0.02\right)$.

Algal assemblages developed in both types of substrates along the experiment recruited 95 genera, $45 \%$ corresponding to diatoms, $20 \%$ to Cyanobacteria, 20\% Chlorophyta, 12\% Charophyta and two genera of Euglenozoa (Table S1). Algal assemblages differed significantly between the grassland and the afforested streams (ANOSIM, $R=0.40$, $p=0.001$ ) as seen in the NMDS ordination (Figure 4, stress $=0.19)$. Also, there were differences among extraction dates (ANOSIM, $R=0.20, p=0.001$ ), but grazing effect was not observed (ANOSIM, $R=0.03, p=0.11$ ). SIMPER analysis revealed some genera contributing most to differences between riparian vegetation types: Fragilaria, Achnanthidium, Encyonema and Gomphonema. These same genera contributed to the difference between extraction dates, adding Phormidium which contributed to the separation of the first extraction time. In the afforested stream, a rise in the proportion of Achnanthidium was observed (Figure 5), mainly in grazed substrates where Phormidium predominated at 23 days (first extraction date). Thus, there were more differences between grazed and ungrazed substrates at 23 than 73 days. In contrast, grassland stream

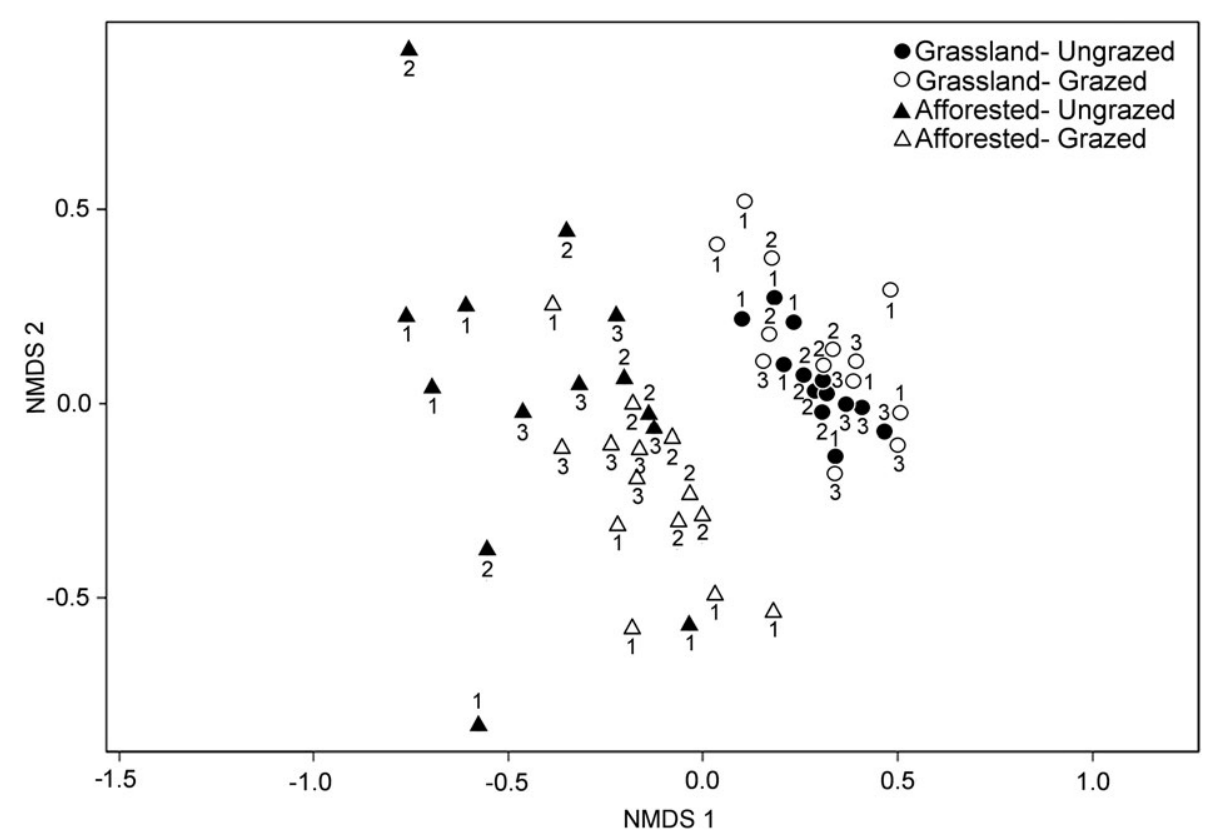

FIGURE 4 NMDS of algal communities in ungrazed and grazed substrates extracted at three dates (1:23 days, 2:45 days and 3:73 days), from the grassland and the afforested stream 
(a)

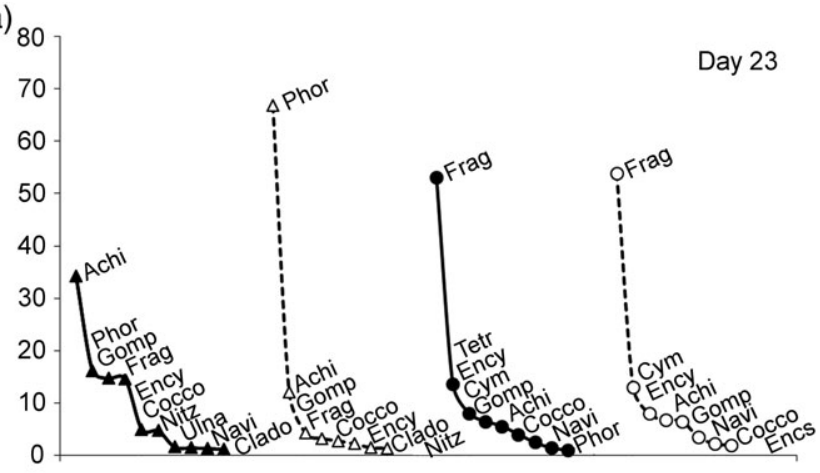

(b) 80

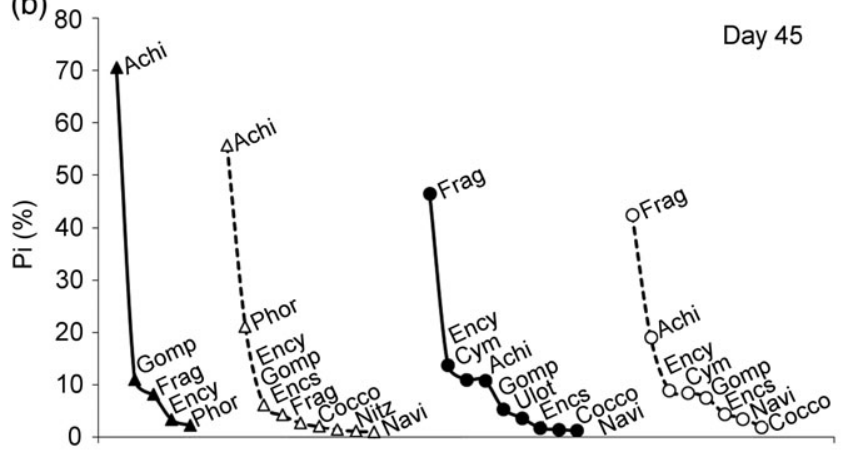

(c)

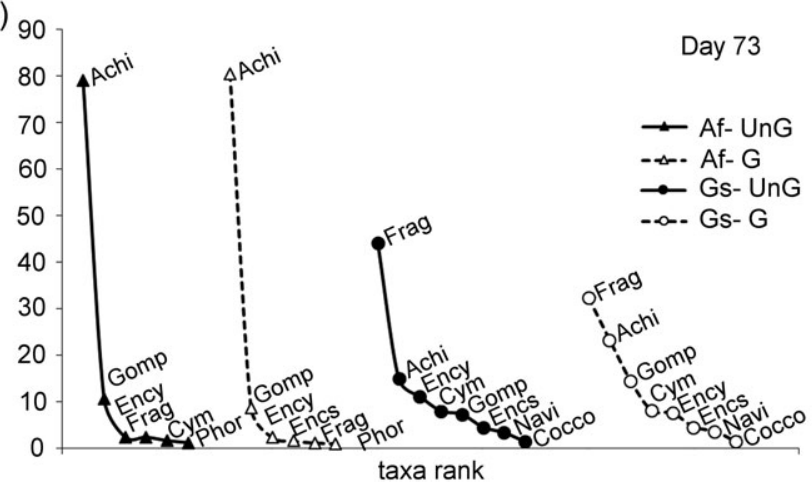

FIGURE 5 Rank-abundance curves for abundant genera (relative abundance $\mathrm{Pi}>1 \%$ ) in ungrazed (UnG) and grazed $(\mathrm{G})$ substrates extracted from the afforested (Af) and the grassland (Gs) stream at three dates (a) 23, (b) 45 and (c) 73 days. Achi: Achnanthidium, Clado: Cladophora, Cocco: Cocconeis, Cym: Cymbella, Ency: Encyonema, Encs: Encyonopsis, Gomp: Gomphonema, Frag: Fragilaria, Navi: Navicula, Nitz: Nitzschia, Phor: Phormidium, Tetr: Tetraspora, Ulna: Ulnaria, Ulot: Ulothrix

communities were similar during the whole experiment. Some differences were the higher proportion of Tetraspora in ungrazed substrates at 23 days and the reduction of Fragilaria proportion in grazed substrates (Figure 5).

When we analyzed independently samples from streams with different riparian vegetation, we found that in the grassland stream, samples corresponding to different dates were separated (stress $=0.17$, ANOSIM for time, $R=0.32$, $p=0.002$ ), but there were no differences due to grazing (ANOSIM for grazing, $R=0.002, p=0.33$ ). Instead, in the afforested stream, we observed differences among assemblages from each extraction date (stress $=0.18$, ANOSIM for time, $R=0.27 ; p=0.003$ ) and also between grazed and ungrazed tiles (ANOSIM for grazing, $R=0.19, p=0.01$ ), due to differences in the first extraction date. Genera that contributed to differences in the afforested stream were Achnanthidium and Phormidium.

Regarding structural variables, most were affected by the three factors, with exception of diversity and evenness that did not show grazing effects (Table 2). Algal density and richness were affected by time, with an increase in the number of organisms and taxa (Figure 6). There was a grazing effect but this varied with riparian vegetation. Communities from the afforested stream showed lower density and richness in ungrazed substrates, while in the grassland stream, ungrazed substrates showed the highest number of taxa. Diversity and evenness of assemblages from the afforested stream decreased with time, while assemblages from the grassland stream showed an increase. Communities from the grassland stream were more diverse and even than communities from the afforested stream, which showed lower values at the end of the experiment.

Regarding the functional traits, few categories were affected by grazing (Table 3 ). The proportion of algae of different sizes changed with time and between streams. Small algae (size class 1) predominated in the afforested stream, while larger algae decreased with time. In the grassland stream, algae of intermediate size predominated (size classes 2 and 3), with a higher proportion of algae of size class 3 in grazed substrates. Morphological guilds varied with time depending on riparian vegetation. In the grassland stream, high profile algae predominated and motile were abundant at 73 days. In the afforested stream, there were a higher proportion of low profile algae, which increased with time, while high profile algae decreased with succession. Motile algae showed higher proportion in grazed substrates. With regard to attachment mechanisms, only algae with mucilage pads and stalks were affected by grazing. Algae with pads showed a higher proportion in the grassland stream, and the difference between grazed and ungrazed substrates increased with time, with a lower proportion in grazed substrates. Stalked algae increased with time in both streams, predominating in the afforested stream (mainly represented by Achnanthidium). Life forms analysis showed that colonial algae were more abundant in the grassland stream, and decreased with time. In addition, the proportion of colonial algae was affected by grazing, with higher abundance in ungrazed substrates. Filamentous forms were more abundant in the afforested stream but also decreased with time. Unicellular algae increased with time in both streams and were more abundant in the afforested streams. FD and FE of functional traits (Table 3, Figure 7) increased with time in the grassland stream and decreased in the afforested stream.

\section{4 | DISCUSSION}

We expected algal communities to be controlled by grazing in grassland streams while to be limited by light in afforested 


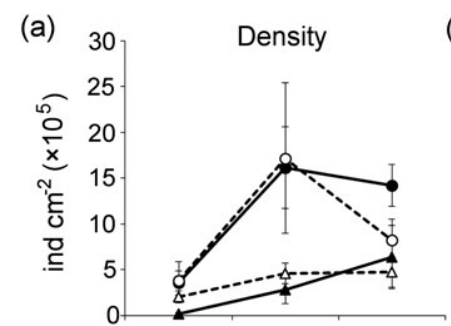

(c)

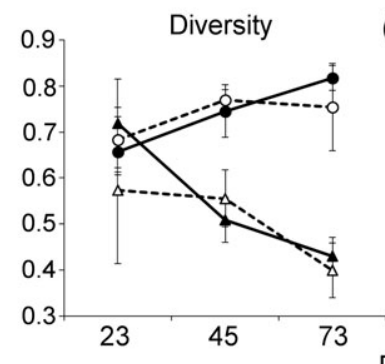

(b)

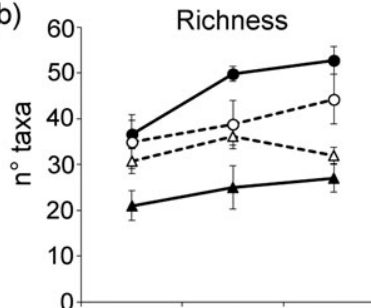

(d) 0.65

Evenness

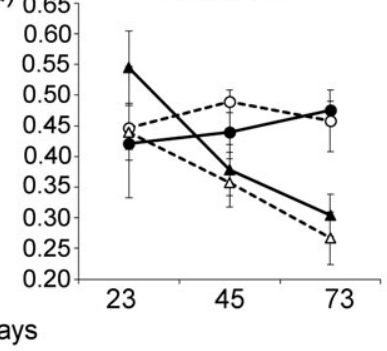

$\longrightarrow$ Grassland- Ungrazed - - - Grassland- Grazed - Afforested- Ungrazed - $\_$- Afforested- Grazed

FIGURE 6 Structural variables of algal communities developed in the afforested and the grassland streams, in grazed and ungrazed substrates, extracted at 23, 45 and 73 days. (a) Density, (b) richness, (c) diversity and (d) evenness. For each variable, mean values and $S D$ are shown

streams (Figure 1). The afforested stream showed the expected results but there are many factors involved in the more complex communities of grasslands streams, given that grazing affected some of the variables that we measured. Then, $70 \%$ of structural and biomass variables responded to grazing. In the grassland stream, grazing reduced richness

TABLE 3 Repeated measures ANOVAs results for functional traits and functional diversity (FD) and evenness (FE) of algal communities developed in afforested (Af) and grassland (Gs) streams (factor vegetation, veg), in grazed (G) and ungrazed substrates (UnG) (factor grazing, Graz), extracted at three dates (factor time, 1, 2 and 3)

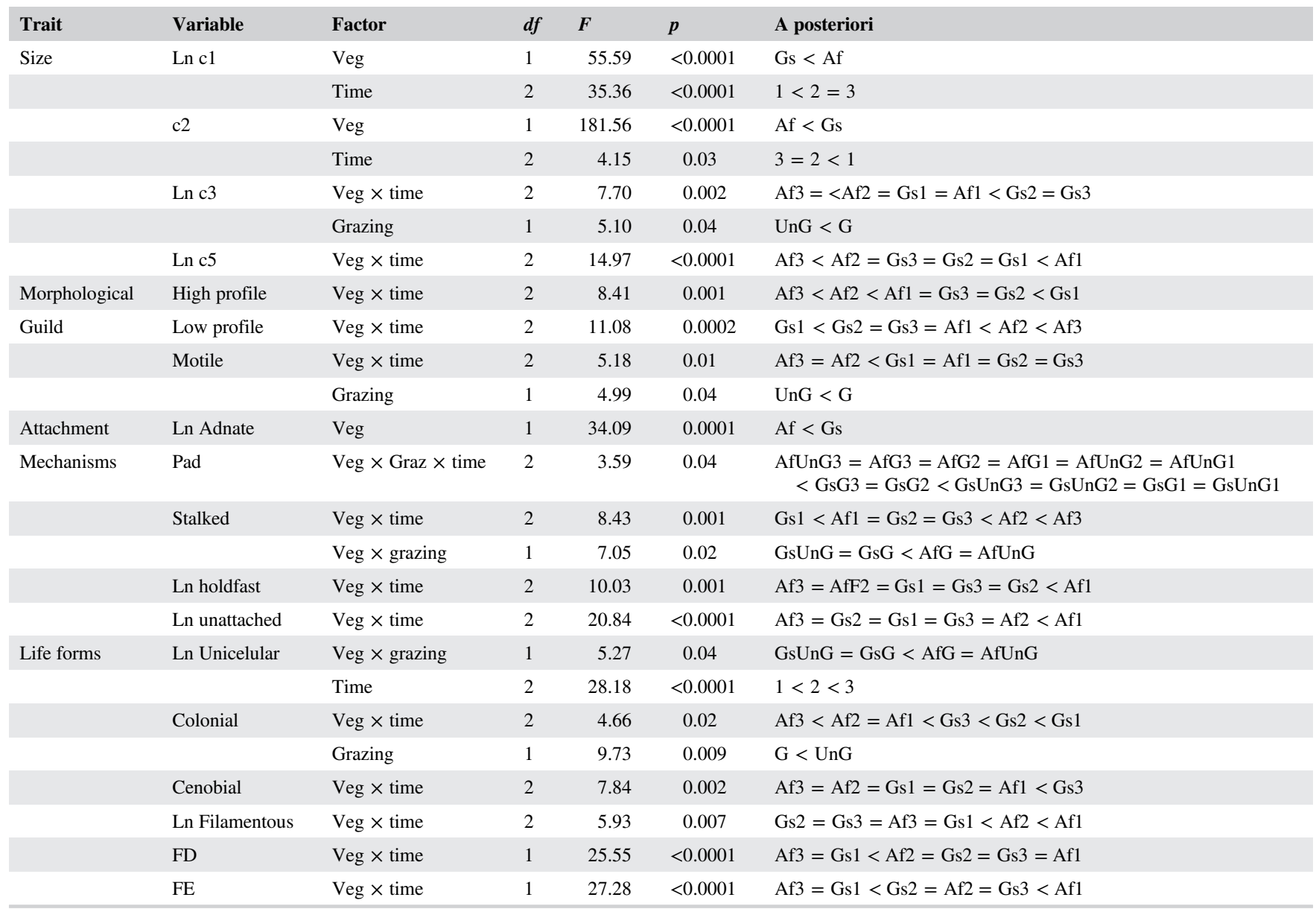

Notes. For each variable, factors that showed a significant effect are shown, with $F$ value, degrees of freedom $(d f), p$ value and a posteriori results. References: $\mathrm{c} 1<99 \mu \mathrm{m}^{3}$, c2 100-299 $\mathrm{m}^{3}$, c3 300-599 $\mu \mathrm{m}^{3}$, c4 600-1,499 $\mu \mathrm{m}^{3}, \mathrm{c} 5>1,500 \mu \mathrm{m}^{3}$, Ln natural logarithm. 


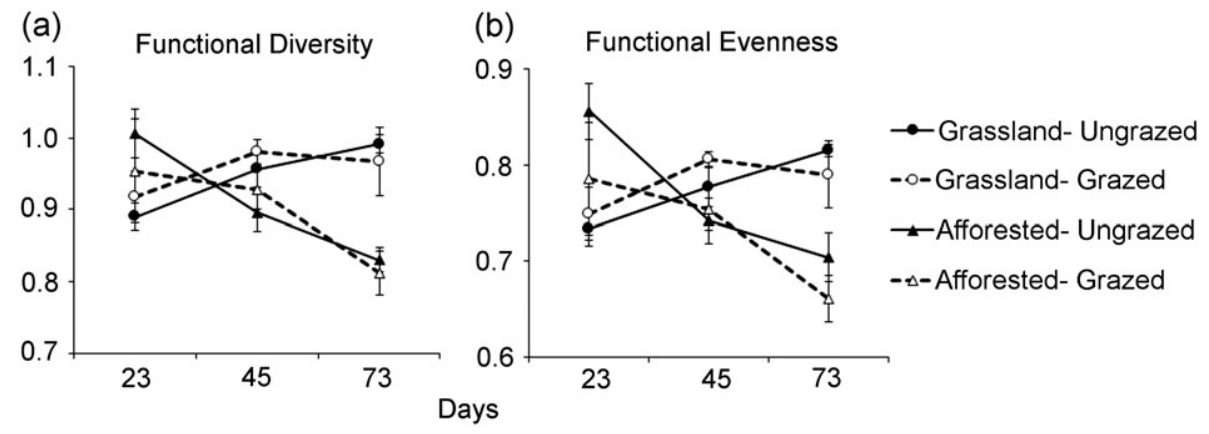

FIGURE 7 (a) Functional diversity and (b) functional evenness of algal communities developed in the afforested and the grassland streams, in grazed and ungrazed substrates, extracted at 23, 45 and 73 days. For each variable, mean values and $S D$ are shown

and AFDM, especially after 45 days, while in the afforested stream, at the same time, grazed substrates showed higher richness and AFDM than ungrazed substrates. NGE showed a higher effect of grazing on algal biomass of grassland streams. In addition, $30 \%$ of functional traits showed grazing effect, but in both stream types. High profile algae predominated in grassland streams, but with a similar proportion in grazed and ungrazed substrates. Nevertheless, ungrazed substrates showed higher proportions of species with pad mucilage and colonial life forms, similar to the expected results. Afforested communities were dominated by low profile species in both substrates, suggesting a higher importance of light in the regulation of algal communities in this stream, in agreement with other studies (Cibils et al., 2015; Cibils-Martina, Principe, et al., 2017; Majdi, Boiché, Traunspurger, \& Lecerf, 2015). In addition, in a previous study which included three grassland and three afforested streams, lower algal abundance and richness, fewer indicator taxa and changes in composition in communities of afforested streams were found; this was mainly attributed to light intensity reduction (Cibils-Martina, Márquez, et al., 2017). Even when the replication of the afforested situation was not possible, we considered that the results of this study contribute to the understanding of how this land use change could affect factors that regulate algal communities.

Community composition showed differences with time in both streams, similar to the reported by Cibils-Martina, Principe, et al. (2017), but multivariate analysis allowed detecting differences between grazed and ungrazed substrates only in the afforested stream. This result is contrary to our prediction and to the findings of other authors (Cibils Martina et al., 2014; Steinman et al., 1989; Wellnitz \& Rader, 2003; Wellnitz \& Ward, 1998) that reported higher grazing effects on substrates exposed to higher light intensity, which favours the development of more productive algal communities. However, as Wellnitz and Rader (2003) stated, periphyton is shaped by multiple factors, and scouring may influence algal composition and response to grazers and light. In our in situ experiment, the differences in the afforested stream were evident with the change in dominance of Phormidium on grazed substrates at the first extraction to the dominance of Achnanthidium. It is likely that Phormidium, which forms a mat over substrates, was easily removed by the growth of algae in the understory, by water flow or by the movement of macroinvertebrates (Holomuzki et al., 2010; Saravia, Giorgi, \& Momo, 2012; Tuchman \& Stevenson, 1991). It would be less likely to attribute the decrease of Phormidium to consumption given its growth form and size since it is a filamentous cyanobacteria that forms densely layered mats which are difficult to consume (Holomuzki et al., 2010). According to Biggs (2000), some invertebrate species seem to avoid large sized algal species as well as filamentous algae since they are difficult to manipulate, and can be of low nutritional value or have chemical compounds that make them unpalatable. The small size and shade tolerance of Achnanthidium minutissimum explains its predominance in the afforested stream (Díaz Villanueva \& Modenutti, 2004; Johnson, Tuchman, \& Peterson, 1997).

In the grassland stream, the same genera predominated on both grazed and ungrazed substrates, similar to the reported by Peterson, Vormittag, and Valett (1998), which offered biofilm developed in 7 days under different grazing conditions (elevated and nonelevated platforms) to two common insect grazers. The lack of differences between substrates may be a result of the predominant genus, Fragilaria, which is tolerant to grazing and compensates loss in abundance with higher reproduction and recolonization rates (Stevenson, Peterson, Kirschtel, King, \& Tuchman, 1991; Sumner \& McIntire, 1982; Wellnitz \& Poff, 2006). Peterson et al. (1998) proposed that there is a trade-off between ingestion resistance and digestion by herbivorous invertebrates, where natural selection would favour digestion resistance in algae easily consumed. This would be the case of Fragilaria, given that these authors found it was more susceptible to be ingested by macroinvertebrates but it was less digestible, allowing it to promptly recolonize substrates. In agreement with our results, Lamberti, Gregory, Ashkenas, Steinman, and McIntire (1989) found a higher grazing effect on the taxonomic structure at lower light incidences, and null grazing effects at higher light intensities, suggesting that algal 
communities reach a similar successional state at high irradiances.

Regarding structural variables, the results obtained for richness are consistent with what was predicted, and are in agreement with the findings of Liess and Hillebrand (2004), given that in the grassland stream a higher number of genera compared to the afforested stream were found in ungrazed substrates. This was also accompanied by higher algal density and biomass. However, higher values of Chl $a$ and lower AFDM were registered in grazed substrates, indicating that grassland stream communities subject to heavy grazing displayed fast recovery. In support of this, Abe et al. (2007) proposed that a higher productivity in assemblages with lower biomass can mitigate grazing effect; as grazers reduce periphyton biomass the ability to generate more biomass increases. NGE results on Chl $a$ and AFDM supported the higher grazing effect on grassland substrates compared to the afforestation. In a previous study in the area, Principe et al. (2015) proposed that higher grazing in grassland streams and heavy shading by afforestation contributed to the lack of differences in biofilm accrual between both stream types, which is confirmed by our results.

Grazing can have a positive effect and stimulate primary production by removing dying and dead cells, changing the assemblage to species more active photosynthetically (e.g., diatoms), facilitating light and nutrients access to lower layers of biofilm, and renewing nutrients by grazer excretions (Holomuzki et al., 2010; Lamberti et al., 1989; Lamberti \& Resh, 1983; Liess \& Haglund, 2007; Rober, Wyatt, \& Stevenson, 2011; Wallace \& Webster, 1996). This phenomenon could explain the higher values of $\mathrm{Chl} a$ in grazed substrates of the grassland stream, suggesting a higher efficiency and metabolic activity of the community exposed to grazers (Huchette, Beveridge, Baird, \& Ireland, 2000; Liess \& Hillebrand, 2004). Furthermore, grazed substrates showed higher values of the autotrophic index at 45 days. At that time, we observed a high vertical development of the community, which a few days later was sloughed, probably because of bubble formation and senescence of inner layers of biofilm, similar to the findings of other researchers (Boulêtreau, Garabétian, Sauvage, \& Sánchez-Pérez, 2006; DeNicola, McIntire, Lamberti, Gregory, \& Ashkenas, 1990; Lamberti et al., 1989; Saravia et al., 2012). In this way, the community was reset leading to a more autotrophic community at 73 days. Interestingly, communities in the afforested stream never reached that state of development and "sloughing off" mechanism. This could explain the reduction of diversity with time in both substrates of the afforested stream, given that a higher frequency of disturbances (due to grazing or current) or self-generated detachment occurring in the grassland stream may increase diversity according to intermediate disturbance hypothesis (Connell, 1978; Peterson, 1996). Ungrazed substrates of the grassland stream were completely covered by masses of
T. lubrica during the experiment, but they were absent 10 days before the final substrate removal, probably as a consequence of periphytic sloughing.

In the afforested stream, algal biomass ( $\mathrm{Chl} a$ and AFDM) did not increase with time, suggesting growth limitation by light (Cibils-Martina, Principe, et al., 2017; Stevenson, 1996). Cibils-Martina, Principe, et al. (2017) also found that succession trajectories were different between grassland and afforested streams, with a longer accrual phase occurring in grassland streams and lower algal biomass in afforested streams. As we expected, in this stream, there were no important differences between grazed and ungrazed substrates in structural or functional attributes. The analysis on functional traits revealed that communities in the afforested stream remained at an early stage of succession, with a predominance of small and low profile algae, consistent with what we expected. Several researchers agree that grazers selectively remove algae more exposed and loosely attached, while prostrate and firmly attached forms resist grazing (Feminella \& Hawkins, 1995; Holomuzki et al., 2010; Liess \& Hillebrand, 2004; McCormick, 1994; McCormick \& Stevenson, 1989). A low proportion of trait categories (33\%) revealed grazing effects, similar to the findings of Wellnitz and Ward (1998), who stated that the substrate which algae are attached to (e.g., detritus or other algae) and their position in the matrix can be better indicators of grazing susceptibility than physiognomy. However, grazed substrates in the grassland stream showed a higher proportion of motile algae and a reduction of algae with pad mucilage and colonial forms. Motile algae have been reported as good competitors since they can avoid unfavourable conditions (Johnson et al., 1997; Lange et al., 2011; Passy, 2007). The reduction of algae with pad mucilage and colonial growth could reflect the consumption of erect algae, which are more exposed in the biofilm, consistent with other studies (Cibils Martina et al., 2014; Holomuzki et al., 2010; Kawamura \& Hirano, 1992; Lange et al., 2011). FD and FE indices were lower in the afforested stream at the end of the experiment, which is in agreement with the results of Cibils et al. (2015). They used other FD indices, one similar to Simpson's index of taxonomic diversity and an index of variance. However, similar to our study, they found that grassland streams had a higher FD than afforested streams. They stated that afforestation reduces FD given that lower light availability lead to periphyton architecture simplification. Instead, higher light levels in grassland streams result in complex algal communities. FD is an important ecological issue because it is linked to the way species share the niche space available in a community (Mason, Mouillot, Lee, \& Wilson, 2005) and has important consequences for the functioning of ecosystems (Díaz et al., 2007).

This study showed that grazers can affect several variables of the algal community's structure and dynamics of succession, and that afforestation has altered the 
development of algal communities and their interaction with grazers. Many researchers have reported marked effects of grazing on stream algal communities, though usually there are interactions with other factors such as light, nutrients, seasonality or higher trophic levels (Buria et al., 2010; Mallory \& Richardson, 2005; Moulton, Lourenço-Amorim, Sasada-Sato, Neres-Lima, \& Zandonà, 2015; Opsahl, Wellnitz, \& Poff, 2003; Rober et al., 2011; Rosemond et al., 2000; Wellnitz \& Ward, 1998). These factors affect abundance and behaviour of grazers (Wellnitz, 2015). Some studies did not find significant effects of grazing because of low grazer densities or high levels of physical disturbances (Hillebrand \& Kahlert, 2002; Lange et al., 2011; Merten, Hintz, Lightbody, \& Wellnitz, 2010), and it is important to consider life history, adaptations and physiological limits of species that dominate grazer assemblage (Wellnitz, 2015). In addition, as pine afforestation not only change light availability but also the input of organic matter, it would be interesting to determine the relative importance of algae in relation to other food resources, as biofilm developed in needle accumulations; likewise, to assess the inhibitory effect of substances released by needles (Bärlocher \& Oertli, 1978; Thompson \& Townsend, 2004).

\section{5 | CONCLUSION}

In conclusion, this experiment showed that top-down and bottom-up forces interact in different ways in grassland and afforested streams. Some structural attributes and functional traits revealed more grazing effects in the grassland stream, and a higher importance of light in the regulation of algal communities in the afforested stream. However, further research can help to understand these complex interactions. This type of study allows assessing changes in time, given that grazing effects tend not to be evident at the beginning of experiments. While algal communities are under dual control of resources and consumers (Rober et al., 2015), the relative strength of bottom-up versus top-down control is different among stream types and the primary regulatory factor can be modified according to land use change.

\section{ACKNOWLEDGMENTS}

The authors would like to thank J. Zanotto Arpellino and S. Abraham for their field efforts. This work was supported by Agencia Nacional de Promoción Científica y Tecnológica (ANPCyT, grant PICT 1113); Ministerio de Ciencia y Tecnología de la provincia de Córdoba (MinCyT Córdoba, grant GRF 08); and Secretaría de Ciencia y Técnica Universidad Nacional de Río Cuarto. LCM and JM were supported by fellowships of Consejo Nacional de Investigaciones Científicas y Técnicas (CONICET), Argentina.

\section{CONFLICTS OF INTEREST}

The authors declare that they have no conflicts of interest.

\section{REFERENCES}

Abe, S., Uchida, K., Nagumo, T., \& Tanaka, J. (2007). Alterations in the biomass-specific productivity of periphyton assemblages mediated by fish grazing. Freshwater Biology, 52, 1486-1493.

Álvarez, M., \& Peckarsky, B. L. (2005). How do grazers affect periphyton heterogeneity in streams? Oecologia, 142, 576-587.

American Public Health Association [APHA]. (1998). Standard methods for examination of water and wastewater (20th ed.). Washington, DC: American Public Health Association, American Water Works Association and the Water and Environment Federation.

Bärlocher, F., \& Oertli, J. J. (1978). Inhibitors of aquatic hyphomycetes in dead conifer needles. Mycologia, 70, 964-974

Biggs, B. J. F. (2000). New Zealand periphyton guideline: Detecting, monitoring and managing enrichment of streams. Christchurch, New Zealand: NIWA for the New Zealand Ministry for the Environment.

Biggs, B. J. F., \& Kilroy, C. (2000). Stream Periphyton monitoring manual. Christchurch, New Zealand: NIWA for the New Zealand Ministry for the Environment.

Boulêtreau, S., Garabétian, F., Sauvage, S., \& Sánchez-Pérez, J. M. (2006) Assessing the importance of a self-generated detachment process in river biofilm models. Freshwater Biology, 51, 901-912.

Buria, L., Albariño, R., Díaz Villanueva, V., Modenutti, B., \& Balseiro, E. (2010). Does predation by the introduced rainbow trout cascade down to detritus and algae in a forested small stream in Patagonia? Hydrobiologia, 651, 161-172.

Cabido, D., Cabido, M., Garré, S. M., Gorgas, J. A., Miatello, R., Ravelo, A., .. Tassile, J. L. (2003). Regiones Naturales de la Provincia de Córdoba, Serie C. [Natural Regions of Córdoba Province]. Córdoba: Publicaciones Técnicas, Agencia Córdoba.

Cibils, L., Principe, R., Márquez, J., Gari, N., \& Albariño, R. (2015). Functional diversity of algal communities from headwater grassland streams: How does it change following afforestation? Aquatic Ecology, 49, 453-466.

Cibils Martina, L., Márquez, J., Principe, R., Gari, N., \& Albariño, R. (2014). Does grazing change algal communities from grassland and pine afforested streams?: A laboratory approach. Limnologica, 49, 26-32.

Cibils-Martina, L., Márquez, J., Principe, R., Gari, N., \& Albariño, R. (2017). Pine afforestation affects key primary producers in mountain grassland streams in Córdoba, Argentina. New Zealand Journal of Marine and Freshwater Research, 51, 591-607.

Cibils-Martina, L., Principe, R., Márquez, J., Gari, N., \& Albariño, R. (2017). Succession of algal communities in headwaters: A comparison of pine afforested and natural grassland streams. Ecological Research, 32, 423-434.

Clarke, K. R., \& Warwick, R. M. (2001). A further biodiversity index applicable to species lists: Variation in taxonomic distinctness. Marine Ecology Progress Series, 216, 265-278.

Connell, J. H. (1978). Diversity in tropical rain forests and coral reefs. Science, 199, 1302-1310

DeNicola, D. M., McIntire, C. D., Lamberti, G. A., Gregory, S. V., \& Ashkenas, L. R. (1990). Temporal patterns of grazer-periphyton interactions in laboratory streams. Freshwater Biology, 23, 475-489.

Di Rienzo, J. A., Casanoves, F., Balzarini, M. G., Gonzalez, L., Tablada, M., \& Robledo, C. W. (2012). InfoStat (versión 2012). Argentina: Universidad Nacional de Córdoba, Grupo InfoStat, FCA Retrieved from http://www. infostat.com.ar

Di Rienzo, J. A., Macchiavelli, R. E., \& Casanoves, F. (2011). Modelos lineales mixtos: Aplicaciones en InfoStat (1a. ed.). [Mixed linear models: applications in InfoStat]. Córdoba: Grupo Infostat.

Díaz, S., Lavorel, S., de Bello, F., Quétier, F., Grigulis, K., \& Robson, M (2007). Incorporating plant functional diversity effects in ecosystem service assessments. Proceedings of the National Academy of Sciences of the United States of America, 104, 20684-20689.

Díaz Villanueva, V., \& Modenutti, B. (2004). Experimental analysis of grazing by the mayfly Meridialaris chiloeensis on different successional stages of stream periphyton. International Review of Hydrobiology, 89, 263-277. 
Dodds, W. K., Gido, K., Whiles, M. R., Fritz, K. M., \& Matthews, W. J. (2004). Life on the edge: The ecology of Great Plains prairie streams. Bioscience, $54,205-216$.

Elschot, K., Vermeulen, A., Vandenbruwaene, W., Bakker, J. P., Bouma, T. J., Stahl, J., ... Temmerman, S. (2017). Top- down vs. bottom-up control on vegetation composition in a tidal marsh depends on scale. PLoS One, 12, e0169960. https://doi.org/10.1371/journal. pone.0169960

Farley, K. A., Piñeiro, G., Palmer, S. M., Jobbágy, E. G., \& Jackson, R. B. (2008). Stream acidification and base cation losses with grassland afforestation. Water Resources Research, 44, 1-11.

Feminella, J. W., \& Hawkins, C. P. (1995). Interactions between stream herbivores and periphyton: A quantitative analysis of past experiments. Journal of the North American Benthological Society, 14, 465-509.

Flecker, A. S., \& Taylor, B. W. (2004). Tropical fishes as biological bulldozers: Density effects on resource heterogeneity and species diversity. Ecology, 85, 2267-2278.

Gordon, N. D., Mcmahon, T. A., \& Finlayson, B. L. (1994). Stream hydrology, an introduction for ecologists. New York, NY: Wiley.

Gruner, D. S., Smith, J. E., Seabloom, E. W., Sandin, S. A., Ngai, J. T., Hillebrand, H., ... Bolker, B. M. (2008). A cross-system synthesis of consumer and nutrient resource control on producer biomass. Ecology Letters, $11,740-755$.

Heino, J. (2005). Functional biodiversity of macroinvertebrate assemblages along major ecological gradients of boreal headwater streams. Freshwater Biology, 50, 1578-1587.

Hill, W. R., Ryon, M. G., \& Schilling, E. M. (1995). Light limitation in a stream ecosystem: Responses by primary producers and consumers. Ecology, 76, 1297-1309.

Hillebrand, H. (2002). Top-down versus bottom-up control of autotrophic biomass: A meta-analysis on experiments with periphyton. Journal of the North American Benthological Society, 21, 349-369.

Hillebrand, H. (2005). Light regime and consumer control of autotrophic biomass. Journal of Ecology, 93, 758-769.

Hillebrand, H., \& Kahlert, M. (2002). Effect of grazing and water column nutrient supply on biomass and nutrient content of sediment microalgae. Aquatic Botany, 72, 143-159.

Holomuzki, J. R., Feminella, J. W., \& Power, M. E. (2010). Biotic interactions in freshwater benthic habitats. Journal of the North American Benthological Society, 29, 220-244.

Huchette, S. M. H., Beveridge, M. C. M., Baird, D. J., \& Ireland, M. (2000). The impacts of grazing by tilapias (Oreochromis niloticus L.) on periphyton communities growing on artificial substrate in cages. Aquaculture, 186, 45-60.

Hunter, M., \& Price, P. (1992). Playing chutes and ladders: Heterogeneity and the relative roles of bottom-up and top-down forces in natural communities. Ecology, 73, 724-732.

Jobbágy, E. G., Acosta, A. M., \& Nosetto, M. D. (2013). Rendimiento hídrico en cuencas primarias bajo pastizales y plantaciones de pino de las sierras de Córdoba (Argentina). [Water yields in primary basins under pastures and pine plantations of the sierras of Córdoba (Argentina)]. Ecología Austral, 23, 87-96.

Jobbágy, E. G., Vasallo, M., Farley, K. A., Piñeiro, G., Garbulsky, M. F., Nosetto, M. D., ... Paruelo, J. M. (2006). Forestación en pastizales: hacia una visión integral de sus oportunidades y costos ecológicos. [Grassland afforestation: towards an integral vision of its ecological opportunities and costs]. Agrociencia, 10, 109-124.

Johnson, R. E., Tuchman, N. C., \& Peterson, C. G. (1997). Changes in the vertical microdistribution of diatoms within a developing periphyton mat. Journal of the North American Benthological Society, 16, 503-519.

Kawamura, T., \& Hirano, R. (1992). Seasonal changes in benthic diatom communities colonizing glass slides in Aburatsubo Bay, Japan. Diatom Research: The Journal of the International Society for Diatom Research, 7, 227-239.

Lamberti, G. A., Ashkenas, L. R., Gregory, S. V., \& Steinman, A. D. (1987) Effects of three herbivores on periphyton communities in laboratory streams. Journal of the North American Benthological Society, 6, 92-104.

Lamberti, G. A., Feminella, J. W., \& Pringle, C. M. (2007). Primary producerconsumer interactions. In F. Hauer \& G. Lamberti (Eds.), Methods in stream ecology (2nd ed., pp. 537-559). Amsterdam, the Netherlands: Elsevier.

Lamberti, G. A., Gregory, S. V., Ashkenas, L. R., Steinman, A. D., \& McIntire, C. D. (1989). Productive capacity of periphyton as a determinant of plant-herbivore interactions in streams. Ecology, 70, 1840-1856.
Lamberti, G. A., \& Resh, V. H. (1983). Stream periphyton and insect herbivores: An experimental study of grazing by a caddisfly population. Ecology, 64, 1124-1135.

Lange, K., Liess, A., Piggott, J. J., Townsend, C. R., \& Matthaei, C. D. (2011). Light, nutrients and grazing interact to determine stream diatom community composition and functional group structure. Freshwater Biology, 56, 264-278.

Larson, C. A., \& Passy, S. I. (2012). Taxonomic and functional composition of the algal benthos exhibits similar successional trends in response to nutrient supply and current velocity. FEMS Microbiology Ecology, 80, 352-362.

Liess, A., \& Haglund, A. L. (2007). Periphyton responds differentially to nutrients recycled in dissolved or faecal pellet form by the snail grazer Theodoxus fluviatilis. Freshwater Biology, 52, 1997-2008.

Liess, A., \& Hillebrand, H. (2004). Invited review: Direct and indirect effects in herbivore-Periphyton interactions. Archiv für Hydrobiologie, 159, 433-453.

Majdi, N., Boiché, A., Traunspurger, W., \& Lecerf, A. (2015). Community patterns and ecosystem processes in forested headwater streams along a gradient of riparian canopy openness. Fundamental and Applied Limnology, 187, 63-78.

Mallory, M. A., \& Richardson, J. S. (2005). Complex interactions of light, nutrients and consumer density in a stream periphyton-grazer (tailed frog tadpoles) system. The Journal of Animal Ecology, 74, 1020-1028.

Márquez, J. A., Cibils, L., Principe, R. E., \& Albariño, R. J. (2015). Stream macroinvertebrate communities change with grassland afforestation in Central Argentina. Limnologica, 53, 17-25.

Martínez, G. A., Arana, M. D., Oggero, A. J., \& Natale, E. S. (2016). Biogeographical relationships and new regionalization of high-altitude grasslands and woodlands of the central Pampean ranges (Argentina), based on vascular plants and vertebrates. Australian Systematic Botany, 29, 473-488.

Mason, N. W. H., Mouillot, D., Lee, W. G., \& Wilson, J. B. (2005). Functional richness, functional evenness and functional divergence: The primary components of functional diversity. Oikos, 111, 112-118.

McCormick, P. V. (1994). Evaluating the multiple mechanisms underlying herbivore-algal interactions in streams. Hydrobiologia, 291, 47-59.

McCormick, P. V., \& Stevenson, R. J. (1989). Effects of snail grazing on benthic algal community structure in different nutrient environments. Journal of the North American Benthological Society, 8, 162-172.

McNeely, C., Finlay, J. C., \& Power, M. E. (2007). Grazer traits, competition, and carbon sources to a headwater-stream food web. Ecology, 88, 391-401.

Merten, E. C., Hintz, W. D., Lightbody, A. F., \& Wellnitz, T. (2010). Macroinvertebrate grazers, current velocity, and bedload transport rate influence periphytic accrual in a field-scale experimental stream. Hydrobiologia, 652, 179-184.

Moulton, T. P., Lourenço-Amorim, C., Sasada-Sato, C. Y., Neres-Lima, V., \& Zandonà, E. (2015). Dynamics of algal production and ephemeropteran grazing of periphyton in a tropical stream. International Review of Hydrobiology, $100,61-68$

Nusch, E. A. (1980). Comparison of different methods for chlorophyll and phaeopigment determination. Archiv für Hydrobiologie, 14, 14-36.

Oggero, A., \& Arana, M. (2012). Inventario de la biodiversidad de plantas vasculares del Sur de la zona Serrana de Córdoba, Argentina. [Inventory of the biodiversity of vascular plants of the south of the mountainous zone of Córdoba, Argentina]. Hoehnea, 39, 171-199.

Oksanen, J., Blanchet, F.G., Kindt, R., Legendre, P., Minchin, P.R., O'Hara, R. B., Simpson, G.L., Solymos, P., Stevens, M.H.H., \& Wagner, H. (2013). Vegan: Community ecology package. R package (version 2.0-8).

Opsahl, R. W., Wellnitz, T., \& Poff, N. L. (2003). Current velocity and invertebrate grazing regulate stream algae: Results of an in situ electrical exclusion. Hydrobiologia, 499, 135-145.

Passy, S. I. (2007). Diatom ecological guilds display distinct and predictable behaviour along nutrient and disturbance gradients in running waters. Aquatic Botany, 86, 171-178.

Peterson, C. G. (1996). Response of benthic algal communities to natural physical disturbance. In R. J. Stevenson, M. L. Bothwell, \& R. L. Lowe (Eds.), Algal ecology: Freshwater benthic ecosystems (pp. 375-402). San Diego, CA: Academic Press.

Peterson, C. G., Vormittag, K. A., \& Valett, H. M. (1998). Ingestion and digestion of epilithic algae by larval insects in a heavily grazed montane stream. Freshwater Biology, 40, 607-623.

Plevich, J., Nuñez, C., Cantero, J., Demaestri, M., \& Viale, S. (2002). Biomasa del pastizal bajo diferentes densidades de pino (Pinus elliottii). [Grass biomass under different pine (Pinus elliottii) densities]. Agroforestería en las Américas, 9, 19-23. 
Power, M. E., Tilman, D., Estes, J. A., Menge, B. A., Bond, W. J., Mills, L. S., ... Paine, R. T. (1996). Challenges in the quest for keystones. Bioscience, 46, 609-620.

Principe, R., Márquez, J., Cibils Martina, L., Jobbágy, E. G., \& Albariño, R. (2015). Pine afforestation changes more strongly community structure than ecosystem functioning in grassland mountain streams. Ecological Indicators, $57,366-375$.

Quinn, G. P., \& Keough, M. J. (2002). Experimental design and data analysis for biologists. Cambridge: University Press.

R Core Team. (2013). R: A language and environment for statistical computing. Vienna, Austria: R Foundation for Statistical Computing Retrieved from: http://www.R-project.org/

Raffaele, E., Núñez, M. A., \& Relva, M. A. (2015). Plantaciones de coníferas exóticas en Patagonia: los riesgos de plantar sin un manejo adecuado. [Exotic conifer plantations in Patagonia: the risks of planting without proper management]. Ecología Austral, 25, 89-92.

Rober, A. R., Stevenson, R. J., \& Wyatt, K. H. (2015). The role of light availability and herbivory on algal responses to nutrient enrichment in a riparian wetland, Alaska. Journal of Phycology, 51, 528-535.

Rober, A. R., Wyatt, K. H., \& Stevenson, R. J. (2011). Regulation of algal structure and function by nutrients and grazing in a boreal wetland. Journal of the North American Benthological Society, 30, 787-796.

Roberts, S., Sabater, S., \& Beardall, J. (2004). Benthic microalgal colonization in streams of differing riparian cover and light availability. Journal of Phycology, 40, 1004-1012.

Rosemond, A. D., Mulholland, P. J., \& Brawley, S. H. (2000). Seasonally shifting limitation of stream periphyton: Response of algal populations and assemblage biomass and productivity to variation in light, nutrients and herbivores. Canadian Journal of Fisheries and Aquatic Sciences, 57, 66-75.

Saravia, L. A., Giorgi, A., \& Momo, F. (2012). Multifractal growth in periphyton communities. Oikos, 121, 1810-1820.

Simberloff, D., Nuñez, M. A., Ledgard, N. J., Pauchard, A., Richardson, D. M., Sarasola, M., ... Ziller, S. R. (2010). Spread and impact of introduced conifers in South America: Lessons from other southern hemisphere regions. Austral Ecology, 35, 489-504.

Steinman, A. D. (1996). Effects of grazers on freshwater benthic algae. In R. J. Stevenson, M. L. Bothwell, \& R. L. Lowe (Eds.), Algal ecology: Freshwater benthic ecosystems (pp. 341-373). San Diego, CA: Academic Press.

Steinman, A. D., McIntire, C. D., Gregory, S. D., \& Lamberti, G. A. (1989). Effects of irradiance and grazing on lotic algal assemblages. Journal of Phycology, 25, 478-485.

Stevenson, R. J. (1996). An introduction to algal ecology in freshwater benthic habitats. In R. J. Stevenson, M. L. Bothwell, \& R. L. Lowe (Eds.), Algal ecology: Freshwater benthic ecosystems (pp. 3-30). San Diego, CA: Academic Press.

Stevenson, R. J. (2010). Algae of river ecosystems. In G. E. Likens (Ed.), River ecosystem ecology: A global perspective (pp. 89-97). San Diego, CA: Academic Press.

Stevenson, R. J., Peterson, C. G., Kirschtel, D. B., King, C. C., \& Tuchman, N. C. (1991). Density-dependent growth, ecological strategies and effects of nutrients and shading on benthic diatom succession in streams. Journal of Phycology, 27, 59-69.

Sumner, W. T., \& McIntire, C. D. (1982). Grazers-periphyton interactions in laboratory streams. Archiv fiur Hydrobiologie, 93, 135-157.

Taylor, B. W., McIntosh, A. R., \& Peckarsky, B. L. (2002). Reach-scale manipulations show invertebrate grazers depress algal resources in streams. Limnology and Oceanography, 47, 893-899.

Thompson, R. M., \& Townsend, C. R. (2004). Impacts of riparian afforestation on streams biofilms: An exotic forest-native grassland comparison New Zealand Journal of Marine and Freshwater Research, 38, 895-902.
Thompson, R. M., \& Townsend, C. R. (2005). Energy availability, spatial heterogeneity and ecosystem size predict food-web structure in streams. Oikos, 108, 137-148.

Thomson, J. R., Taylor, M. P., Fryirs, K. A., \& Brierley, G. J. (2001). A geomorphological framework for river characterization and habitat assessment. Aquatic Conservation, 11, 373-389.

Tuchman, N. C., \& Stevenson, R. J. (1991). Effects of selective grazing by snails on benthic algal succession. Journal of the North American Benthological Society, 10, 430-443.

Villafañe, V. E., \& Reid, F. M. H. (1995). Métodos de microscopía para la cuantificación del fitoplancton. [Microscopy methods for the quantification of phytoplankton]. In K. Alveal, M. E. Ferrario, E. C. Oliveira, \& E. Sar (Eds.), Manual de Métodos Ficológicos [Manual of Phycological Methods] (pp. 169-185). Concepción, Chile: Edit. Universitaria.

Wallace, J. B., \& Webster, J. R. (1996). The role of macroinvertebrates in stream ecosystem function. Annual Review of Entomology, 41, 115-139.

Weber, C. I. (1973). Biological monitoring of the aquatic environment. In J. Cairns, Jr. \& K. L. Dickson (Eds.), Biological methods for the assessment of water quality, ASTM STP 528 (pp. 46-60). Philadelphia, PA: American Society of Testing and Materials.

Wellnitz, T. (2015). How do stream grazers partition their benthic habitat? Hydrobiologia, 760, 197-204. https://doi.org/10.1007/s10750-015-2326-x

Wellnitz, T., \& Poff, N. L. (2006). Herbivory, current velocity and algal regrowth: How does periphyton grow when the grazers have gone? Freshwater Biology, 51, 2114-2123.

Wellnitz, T., \& Rader, R. (2003). Mechanisms influencing community composition and succession in mountain stream periphyton: Interactions between scouring history, grazing, and irradiance. Journal of the North American Benthological Society, 22, 528-541.

Wellnitz, T., \& Ward, J. V. (1998). Does light intensity modify the effect mayfly grazers have on periphyton? Freshwater Biology, 39, 135-149.

Wellnitz, T., \& Ward, J. V. (2000). Herbivory and irradiance shape periphytic architecture in a Swiss alpine stream. Limnology and Oceanography, 45, 64-75.

Werner, F. J., \& Matthiessen, B. (2013). Temperature indirectly affects benthic microalgal diversity by altering effects of top-down but not bottom-up control. Oikos, 122, 52-63.

Whiting, D. P., Whiles, M. R., \& Stone, M. L. (2011). Patterns of macroinvertebrate production, trophic structure, and energy flow along a tall grass prairie stream continuum. Limnology and Oceanography, 56, 887-898.

Winkelmann, C., Schneider, J., Mewes, D., Schmidt, S. I., Worischka, S., Hellmann, C., \& Benndorff, J. (2014). Top-down and bottom-up control of periphyton by benthivorous fish and light supply in two streams. Freshwater Biology, 59, 803-818.

\section{SUPPORTING INFORMATION}

Additional supporting information may be found online in the Supporting Information section at the end of the article.

How to cite this article: Cibils-Martina L, Márquez JA, Gari EN, Albariño RJ, Principe RE. Disentangling grazing and light controls on algal communities in grassland and afforested streams. Ecol. Res. 2019;34:136-149. https://doi.org/10.1111/ 1440-1703.1014 